\title{
Sub-Milankovitch climatic cycles in Holocene stalagmites from Sauerland, Germany
}

\author{
Stefan Niggemann ${ }^{\mathrm{a}, \mathrm{b}, *}$, Augusto Mangini ${ }^{\mathrm{c}}$, Manfred Mudelsee ${ }^{\mathrm{d}, 1}$, \\ Detlev K. Richter ${ }^{b}$, Georg Wurth ${ }^{b}$ \\ a Dechenhöhle und Cave Museum, Dechenhöhle 5, D-58644 Iserlohn, Germany \\ b Institut für Geologie, Mineralogie und Geophysik, Ruhr-Universität Bochum, Universitätsstr. 150, D-44801 Bochum, Germany \\ c Heidelberger Akademie der Wissenschaften, Im Neuenheimer Feld 229, D-69120 Heidelberg, Germany \\ d Institut für Meteorologie, Universität Leipzig. Stephanstr. 3, D-04103 Leipzig, Germany
}

Received 13 February 2003; received in revised form 7 August 2003; accepted 8 September 2003

\begin{abstract}
Calcitic stalagmites from caves in the Sauerland, Germany, prove the existence of sub-Milankovitch cycles in precipitation during the last $6000 \mathrm{yr}$. The $\delta^{18} \mathrm{O}$ record dated with $\mathrm{Th} / \mathrm{U}$ is interpreted as an indicator of paleohumidity. Spectral analysis of $\delta^{18} \mathrm{O}$ from 6000 a BP up to the recent top of a stalagmite from the Atta cave yields statistically significant peaks at 1450,117, 64 and 57 a. Additionally we find a good correlation of the stalagmite's $\delta^{18} \mathrm{O}$ and $\Delta^{14} \mathrm{C}$ from European tree rings. The 1450 a cycle in the stalagmite probably is analogous to the pervasive millennial scale climate cycle described by Bond et al. [Science 278 (1997) 1257-1266; 294 (2001) 2130-2136] derived from the amount of ice rafted debris in deep sediments from the North Atlantic. Our results suggest that the centennial to millennial shifts observed in the North Atlantic are accompanied by synchronous shifts of the climate in Northern and Central Europe, which most probably can be attributed to solar irradiation variations.
\end{abstract}

(C) 2003 Elsevier B.V. All rights reserved.

Keywords: Holocene; stalagmite; $\delta^{18} \mathrm{O}$ record; paleohumidity; climatic cycle; Germany

\footnotetext{
* Corresponding author. Tel.: +49-2374-71421; Fax: +49-2374-750100.

E-mail addresses: dechenhoehle@t-online.de
} (S. Niggemann), augusto.mangini@iup.uni-heidelberg.de (A. Mangini), mudelsee@rz.uni-leipzig.de (M. Mudelsee).

\footnotetext{
1 Present address: Department of Earth Sciences, Boston University, 685 Commonwealth Avenue, Boston, MA 02215, USA.
}

\section{Introduction}

The study of deep sea sediments from the Northern Atlantic documents that the Earth's climate may be very sensitive to extremely weak perturbations in the Sun's energy output, not only on the decadal scale but also on centennial to millennial scales [2]. Very prominent features of the North Atlantic's Holocene climate are recorded as a series of shifts of North Atlantic hydrology, when drift ice and cooler surface waters were repeatedly advected southwards and eastwards. 
Calcitic stalagmites are excellent archives for ambient conditions and $\mathrm{Th} / \mathrm{U}$ dating delivers a reliable chronology of the periods of stalagmite formation. Growth rates ranging from some microns to several hundred microns per year allow high temporal resolution.

Stalagmites from key localities, where periods of growth imply a shift of climatic boundaries, may be used as reliable climatic archives. For example, the growth periods of stalagmites indicate that local temperatures periodically exceeded a certain temperature threshold in the past. These 'simpler' features were successfully applied to localities in Alpine regions or in Northern Oman. In the Alps growth of stalagmites implies periodic lowering of the permafrost boundary [3-5]. In the desert it corresponds to periodic increase of precipitation in the past [6-8].

The signal of stable isotopes in calcitic stalagmites consists in principle of that of the ambient precipitation, and of the equilibrium fractionation during calcite formation, which is a function of the temperature in the cave. However, this signal may be heavily altered by kinetic processes (evaporation), as well as by addition of seepage water with a different isotopic composition. The unraveling of the oxygen isotopic signals in stalagmites is a well-known problem but, although much advance has been made in stable isotopes of speleothems since the work of Fantidis and Ehhalt [9], transforming the isotopic signal into an absolute temperature is most uncertain or nearly impossible. Nevertheless, the enrichment of heavier stable isotopes of the calcite may be used as an indicator of lower humidity in a cave due to less dripping activity caused by less precipitation $[6,7,10]$. A high-resolution profile of oxygen isotopes on a stalagmite from South Oman even shows the 11 yr solar cycle [8]. Drier periods then are recorded as maxima of $\delta^{18} \mathrm{O}$ together with maxima of $\delta^{13} \mathrm{C}$. In the Hoti cave in Northern Oman peaks of $\delta^{18} \mathrm{O}$ ascribed to reduced precipitation have a high coherence with peaks of $\Delta^{14} \mathrm{C}$, suggesting that the position of the ITCZ is influenced by solar inten-

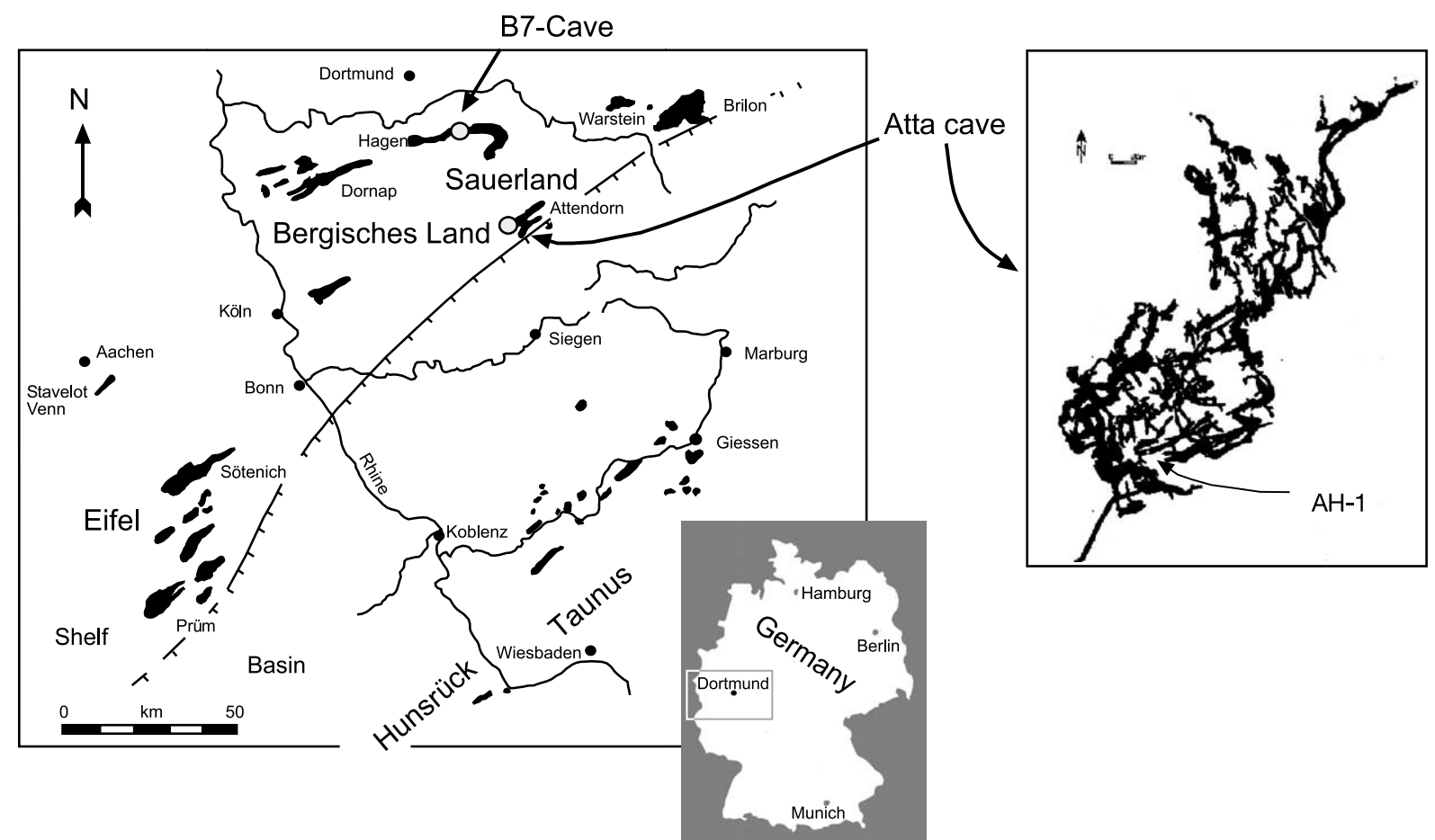

Fig. 1. Map showing the Middle Devonian shelf-basin transition (diagonal line) and massive limestone occurrences (black areas) in the Rhenish Slate Mountains. Gray points are the localities of the B7 cave and the Atta cave. Map of the Atta cave with growth location of stalagmite AH-1. 
sity (which is assumed to be the cause for the variability of $\Delta^{14} \mathrm{C}$ ) [6,7]. A positive relationship between $\delta^{18} \mathrm{O}$ and $\Delta^{14} \mathrm{C}$ has also been recently reported in the B7 cave in Northwestern Germany [10] for a stalagmite that grew during the last 4000 yr, however at a much lower time resolution than in the samples from Northern Oman. A statistically significant correlation of tree ring $\Delta^{14} \mathrm{C}$ and speleothem optical density luminescence (indicating annual lamination density) has also been described for a stalagmite from Iowa [11].

In this study we analyzed a stalagmite from the Atta cave, located some $60 \mathrm{~km}$ south of the B7 cave in Northwestern Germany. The purpose was to check if our preliminary results on stalagmites from the B7 cave [10] could be duplicated. Also, we wanted to achieve a better time resolution than in the B7 sample, and so to test if the centennial to millennial shifts observed in the North Atlantic by Bond et al. [1,2] are accompanied by synchronous shifts of the climate in Northern Europe. Also, the length of our stalagmite record allows an excellent testing of Bond cycles for a continental archive.

\section{Sample location, methods and results}

The Atta cave situated in the Bigge valley near Attendorn is the biggest cave in the Sauerland region and one of the biggest caves in Germany with a total length of $6700 \mathrm{~m}$ (Fig. 1). The karstic area consists of Middle Devonian massive limestone with atoll-like biohermal reef sediments above a biostromal base. About 80 caves, most of which are small, are documented in the Attendorn-Elspe-Double-Syncline [12]. The cave extends below the $308 \mathrm{~m}$ a.s.l. high Stürzenberg. The analyzed $61 \mathrm{~cm}$ long stalagmite, $\mathrm{AH}-1$, was taken from a $5 \mathrm{~m}$ high fault orientated cave gallery, $3 \mathrm{~m}$ above the modern ground water table. No flooding of the stalagmite in recent times could be observed. The location of AH-1 is situated $50 \mathrm{~m}$ below the surface and over $100 \mathrm{~m}$ away from both the original and the artificial cave entrance representing real cave climate ( $>98 \%$ humidity, constant temperature of $9.4^{\circ} \mathrm{C}$ ). Although the gallery leads to the eastern part of the com-

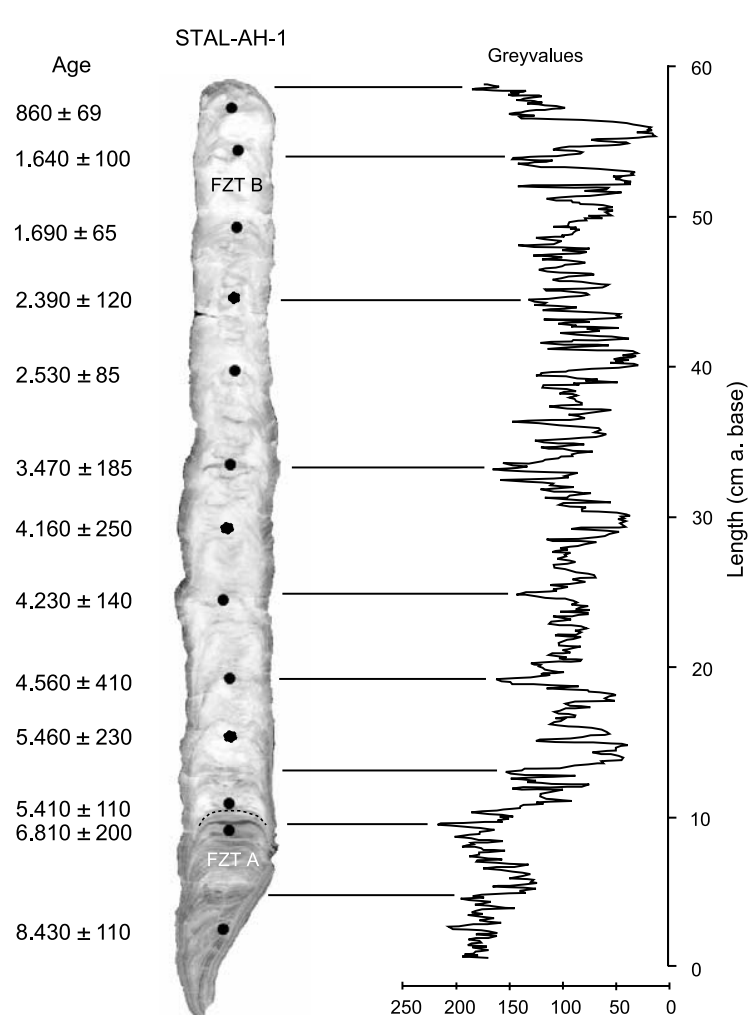

Fig. 2. Photography of the polished length section of stalagmite AH-1 with the TIMS ages and gray values (0-255) representing the microfacies.

plex cave system nearly no air flow could be detected. The stalagmite grew on a $1 \mathrm{~cm}$ thin sinter layer and was fed by a small soda straw stalactite on the ceiling of the gallery. During a 10 month monitoring campaign (March 1997-January 1998) no interruption of dripping could be observed [13]. The dripping waters are saturated in respect of calcite [saturation index (SI): $0.26 \pm 0.16$; $n=11]$ so no dissolution occurs. The SI values range from 0.05 to 0.61 . The highest values are observed during the winter season together with the highest dripping rates. Additionally, eight drip water samples at AH-1 were monthly taken for analyzing the oxygen isotopic composition. The mean value is $-8.92 \pm 0.2 \%$ (SMOW). To detect the seasonal $\mathrm{CO}_{2}$ changes for the cave air a monitoring campaign has just started.

The surface of the stalagmite is white and near the base brownish, only near the top is the color light gray, which is caused by dust particles 
Table 1

Th/U ages

\begin{tabular}{|c|c|c|c|c|c|c|c|c|c|c|c|c|c|c|}
\hline $\begin{array}{l}\text { Lab. } \\
\text { No. }\end{array}$ & Name & $\begin{array}{l}\text { Distance } \\
\text { from top } \\
(\mathrm{cm})\end{array}$ & $\begin{array}{l}\delta^{234} \mathrm{U} \\
\text { (corr.) } \\
(\% 0)\end{array}$ & $\begin{array}{l} \pm \\
(\% 0)\end{array}$ & $\begin{array}{l}\text { Conc. }{ }^{238} \\
\left(\mu \mathrm{g} \mathrm{g}^{-1}\right)\end{array}$ & $\begin{array}{l} \pm \\
\left(\mu g^{-1}\right)\end{array}$ & $\begin{array}{l}\text { Conc. }{ }^{232} \mathrm{Th} \\
\left(\mathrm{ng} \mathrm{g}^{-1}\right)\end{array}$ & $\begin{array}{l} \pm \\
\left(n g g^{-1}\right)\end{array}$ & $\begin{array}{l}\text { Conc. } \\
{ }^{230} \mathrm{Th} \\
\left(\mathrm{fg} \mathrm{g}^{-1}\right)\end{array}$ & $\begin{array}{l} \pm \\
\left(f g g^{-1}\right)\end{array}$ & $\begin{array}{l}\text { Age } \\
\text { (corr.) } \\
\text { (ka) } \\
\end{array}$ & $\begin{array}{l} \pm \\
(\mathrm{ka})\end{array}$ & $\begin{array}{l}\text { Age } \\
\text { (uncorr.) } \\
\text { (ka) }\end{array}$ & $\begin{array}{l} \pm \\
(\mathrm{ka})\end{array}$ \\
\hline 1756 & AH-1 (2.0) & $2.0 \pm 0.3$ & 992.8 & 9.1 & 0.13087 & 0.00021 & 0.64121 & 0.0043 & 36 & 2.8 & 0.86 & 0.069 & 0.93 & 0.075 \\
\hline 1757 & AH-1 (4.5) & $4.5 \pm 0.3$ & 960.8 & 6 & 0.17414 & 0.00021 & 0.0277 & 0.0002 & 83 & 4.9 & 1.64 & 0.1 & 1.6 & 40.1 \\
\hline 1691 & AH-1 (10.2) & $10.2 \pm 0.3$ & 972.5 & 8.1 & 0.21043 & 0.00042 & 0.1824 & 0.0018 & 105.2 & 3.8 & 1.69 & 0.065 & 1.71 & 0.07 \\
\hline 1956 & AH-1 (14.5) & $14.5 \pm 0.3$ & 1011.5 & 13.6 & 0.1598 & 0.00038 & 0.3164 & 0.003 & 115.1 & 5.2 & 2.39 & 0.12 & 2.42 & 0.13 \\
\hline 1694 & AH-1 (19.3) & $19.3 \pm 0.3$ & 1030.1 & 8.2 & 0.14663 & 0.00029 & 0.17635 & 0.00072 & 112.1 & 3.4 & 2.53 & 0.085 & 2.54 & 0.09 \\
\hline 1806 & AH-1 (25.7) & $25.7 \pm 0.3$ & 1034.8 & 13.2 & 0.16184 & 0.0005 & $<0.1$ & & 168.7 & 7.8 & 3.47 & 0.185 & 3.47 & 0.19 \\
\hline 1957 & AH-1 (30.0) & $30.0 \pm 0.3$ & 1043.1 & 11.8 & 0.15235 & 0.00026 & $<0.1$ & & 191.2 & 10.1 & 4.16 & 0.25 & 4.17 & 0.25 \\
\hline 1695 & AH-1 (34.0) & $34.0 \pm 0.3$ & 1041.7 & 9.1 & 0.16348 & 0.00033 & 0.1766 & 0.0011 & 208.9 & 5.6 & 4.23 & 0.14 & 4.25 & 0.14 \\
\hline 1758 & AH-1 (39.5) & $39.5 \pm 0.3$ & 1067.1 & 19.6 & 0.15543 & 0.00062 & 0.329 & 0.011 & 216.9 & 17.4 & 4.56 & 0.41 & 4.59 & 0.42 \\
\hline 1958 & AH-1 (43.7) & $43.7 \pm 0.3$ & 1045.8 & 21.5 & 0.18547 & 0.00061 & 1.0771 & 0.0081 & 308.1 & 9.2 & 5.46 & 0.23 & 5.54 & 0.23 \\
\hline 1696 & AH-1 (48.2) & $48.2 \pm 0.3$ & 1040.8 & 6.4 & 0.18639 & 0.00037 & 0.1723 & 0.0012 & 302.2 & 5.1 & 5.41 & 0.11 & 5.42 & 0.11 \\
\hline 1759 & AH-1 (50.2) & $50.2 \pm 0.3$ & 1062.1 & 19.8 & 0.2049 & 0.001 & 0.7177 & 0.006 & 422.6 & 8 & 6.81 & 0.2 & 6.86 & 0.21 \\
\hline 1643 & AH-1 (55.3) & $55.3 \pm 0.3$ & 978.6 & 6.6 & 0.19711 & 0.00039 & 1.4707 & 0.0057 & 481.8 & 4.4 & 8.43 & 0.11 & 8.53 & 0.12 \\
\hline
\end{tabular}

Errors are quoted as $2 \sigma$ standard deviations. The correction for the detritus contamination was performed applying the following three assumptions: (i) the detrital ${ }^{238} \mathrm{U} /{ }^{232} \mathrm{Th}$ activity ratios are close to the upper continental value taking the $\mathrm{Pb}$ isotope evolution into account $(0.764$, Th/ $\mathrm{U}$ mass ratio of 4.1 in [17]); (ii) initial non-detrital ${ }^{230} \mathrm{Th}$ is equal to 0 ; and (iii) radioactive equilibrium exists between detrial ${ }^{230} \mathrm{Th}-{ }^{234} \mathrm{U}$ and ${ }^{238} \mathrm{U}$. Also listed in columns 14 and 15 are the uncorrected ages. Except for the sample from $2 \mathrm{~cm}$ distance from the top, the corrected ages are the same as the uncorrected ages within their limits of uncertainty. 


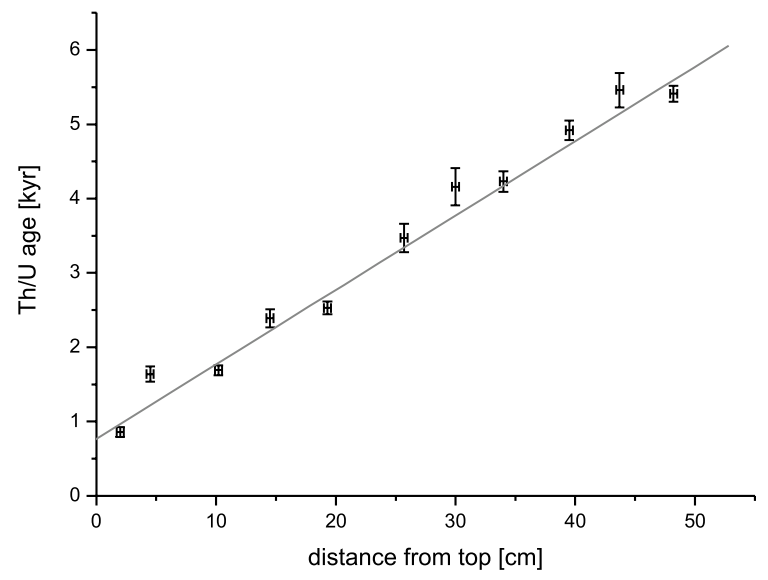

Fig. 3. Depth-age relationship derived for stalagmite AH-1. $\mathrm{Th} / \mathrm{U}$ ages are calendar ages and were derived as described in [6].

brought in the cave by very slow air circulation and by visitors after the discovery and opening of the cave for tourists in 1907.

For stalagmites two distinct facies zones were described that contain five microfacies types depending on the amount of fluid inclusions $[14,15]$. This description applies also to AH-1 where dark compact facies with no or little porosity and white porous facies zones alternating in four different hierarchies lead to a macroscopically or microscopically visible light-dark layering pattern $[13,16]$. This pattern is recorded by a gray value analyzing procedure (Fig. 2 [13]) but between about $6 \mathrm{ka}$ and $1 \mathrm{ka}$ BP white porous microfacies are strongly dominating.

Thirteen TIMS Th/U ages reveal the growth pattern of the stalagmite (Table 1; Figs. 2 and $3)$. The growth rate in the basal part was about $30 \mu \mathrm{m} / \mathrm{a}$. The uniform and relatively high growth rate of about $100 \mu \mathrm{m} / \mathrm{a}$ in the middle part, between 5400 and 860 a BP, is an advantage for constructing time series of geochemical and microfacial parameters. Near the top for the last $860 \mathrm{yr}$ the growth rate again slows down to 20 $\mu \mathrm{m} / \mathrm{a}$. The transformation of the depth scale into a calibrated age scale was performed applying a constant growth rate between 1500 and $5500 \mathrm{yr}$. We use a linear regression model due to the excellent correlation coefficient $\left(r^{2}=0.98 ; n=11\right)$ without any outliers. The white porous facies in the middle section have grown three times faster than the dark compact layers at the base $(>5.5$ ka BP) and the top $(<0.86 \mathrm{ka} \mathrm{BP})$, which is in accordance with recently published data $[13,18]$.

Three hundred and eighty-four samples for isotopic analyses $\left(\delta^{18} \mathrm{O}, \delta^{18} \mathrm{C}\right)$ were taken with a mean distance of $1.5 \mathrm{~mm}$ at least in the white porous dominating middle and upper unit of the stalagmite. The temporal resolution in this part is about 15 yr. Additionally, five samples of the basal sinter layer on which the stalagmite has grown were isotopically analyzed. The $\delta^{18} \mathrm{O}$ within the stalagmite ranges from -6.86 to $-4.99 \%$ o with a mean value of $-5.90 \pm 0.32 \%$ and the $\delta^{13} \mathrm{C}$ from $-6.83 \%$ to $-3.20 \%$ with a mean value of $-5.92 \pm 0.49 \%$ o $(n=384)$. As shown in Fig. $4, \delta^{18} \mathrm{O}$ and $\delta^{13} \mathrm{C}$ correlate slightly $(r=0.37$, $\mathrm{CI}=[0.27 ; 0.46], n=384$ where $r$ is Pearson's correlation coefficient, CI denotes the $95 \%$ bootstrap confidence interval for $r$ [19] and $n$ is the sample size). Hendy tests [20] along a single growth layer could not be realized due to the diffuse lamination of the stalagmite.

White porous facies are the result of fast growth rates caused by high supersaturation and/or evaporation with kinetic growth effects (e.g. frequent seasonally driven dripping interruptions).

There exists only a small correlation between gray values/facies types and $\delta^{18} \mathrm{O}$ within the stalagmite profile $(r=0.20, \mathrm{CI}=[0.10 ; 0.31], n=384$; cf. [19]) and the mean values of $\delta^{18} \mathrm{O}$ for light porous and dark compact facies are the same. The basal sinter layer shows no deviation from the stalagmite oxygen isotopic range.

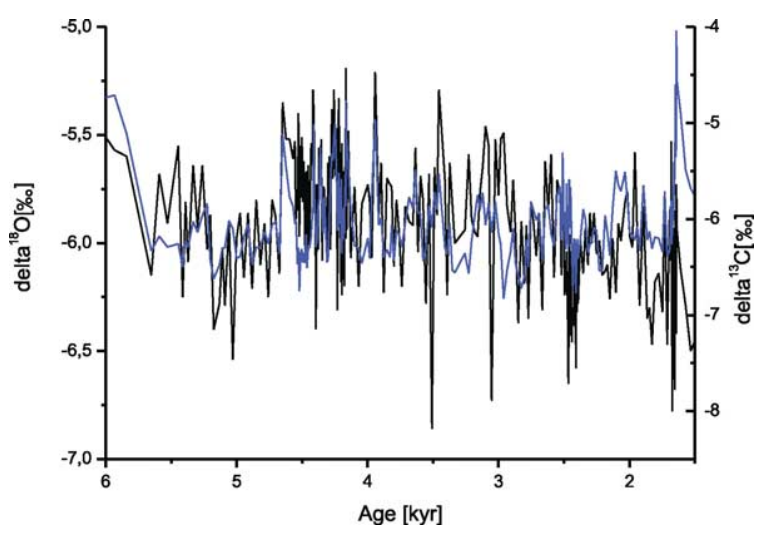

Fig. 4. Correlation of $\delta^{18} \mathrm{O}$ and $\delta^{13} \mathrm{C}$ (blue) along the length section of stalagmite $\mathrm{AH}-1$ (both scales tuned). 


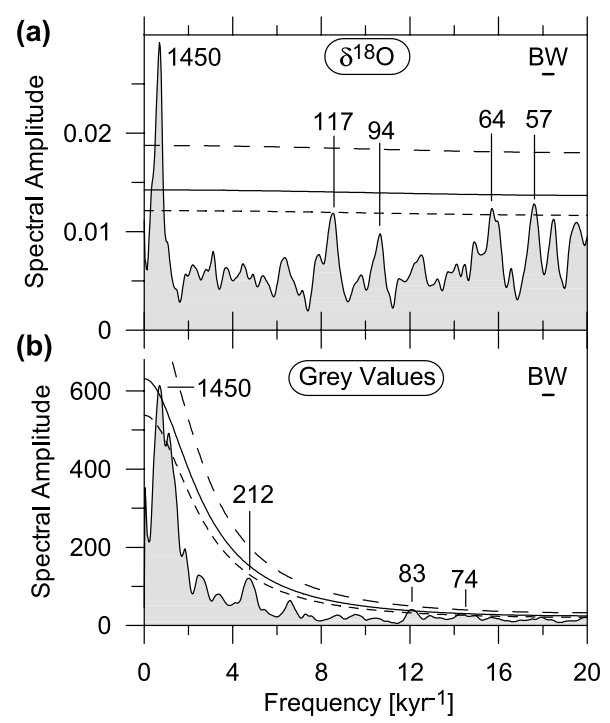

Fig. 5. Spectral analyses of the $\delta^{18} \mathrm{O}$ (a) and gray value (b) records from stalagmite AH-1. Spectral peaks are labelled with their period (in yr). Both time series were detrended prior to the analysis by removing signals with periods above the $2000 \mathrm{yr}$ period using a filter algorithm [24]. The spectra (shaded in a and b) were estimated with the Lomb-Scargle Fourier transform for unevenly spaced data, the Welch overlapped-segment-averaging procedure (four segments with $50 \%$ overlap), linear detrending for each segment and a Welch I data taper. The spectra were bias-corrected using 2000 Monte Carlo simulations [21]. Shown as red-noise alternatives are upper chi-squared bounds (smooth lines in a and $\mathrm{b}$; significance levels: 90\% (short-dashed), 95\% (solid) and 99\% (long-dashed)) of a first order autoregressive (AR1) process. The AR1 process was fitted using the time-domain algorithm of Mudelsee [22] to the time series subsequent to removal of harmonic peaks, yielding equivalent autocorrelation coefficients of 0.01 (nearly white noise) (a) and 0.67 (b). The $6 \mathrm{~dB}$ bandwidth $(\mathrm{BW})$, determining the frequency resolution, is $0.46 \mathrm{kyr}^{-1}(\mathrm{a}, \mathrm{b})$. The spectra were calculated with software REDFIT [21].

Spectral analysis for gray values, $\delta^{18} \mathrm{O}$ and $\delta^{13} \mathrm{C}$ was performed using the program REDFIT 3.5 [21]. The spectral variance of $\delta^{18} \mathrm{O}$ depicts in Fig. 5a a major peak at $1450(1086-2186)$ yr that exceeds the $99 \%$ chi-squared limit of confidence. Other minor peaks are seen at 117 (114-120), 94 (9296), 64 (63-65) and 57 (56-58) yr. The values in the parentheses represent the bandwidth interval. A 1450 a cycle is also detected in the gray value profile of the stalagmite (Fig. 5b). The period of $1450 \mathrm{a}$ is contained in the $4000 \mathrm{yr}$ record 2.7 times which is statistically sufficient [23,24].

\section{Discussion}

The growth rate has been rather constant at a value of about $100 \mu \mathrm{m} / \mathrm{yr}$ throughout the white porous interval from approximately 1500 to $5500 \mathrm{yr}$ BP (Figs. 2 and 3). The average $\delta^{18} \mathrm{O}$ of the calcite in this section of AH-1 is $-6 \pm 0.32 \%$, with peaks of $\delta^{18} \mathrm{O}$ reaching up to $-5.2 \%$. These values are close to the value of $-5.87 \%$ in presently precipitated calcite on top of the stalagmite but largely exceed the expected $\delta^{18} \mathrm{O}$ value of -6.9 to $-7.3 \%$ o for calcite formed in equilibrium with the dripping water (ranging between $-9.1 \%$ o and $-8.7 \%$ (SMOW) at the annual average temperature in the cave of $9.4^{\circ} \mathrm{C}$ ).

Significantly higher $\delta^{18} \mathrm{O}$ of the calcite $(>+1 \%$ o had also been observed in stalagmite B7-7 from the B7 cave and in speleothems from other caves [10,13,25]. Also, it is interesting to note that in both $\mathrm{AH}-1$ and in $\mathrm{B} 7-7$ the lowest isotopic values are at about $-7 \%$, closer to the expected equilibrium values for calcite at $-7.3 \%$ o (AH-1) and $-6.5 \%$ (B7-7), respectively.

The white porous section between 5.5 and $1 \mathrm{ka}$ BP with its constant high growth rate is composed of diffuse laminae probably developed during frequent dripping interruptions. This could result from evaporation in water films on the stalagmite's surface [10]. The comparison of the drip waters with the calcite in the AH-1 sample confirms the general trend towards heavier values of $\delta^{18} \mathrm{O}$ in the calcite, probably due to periodic lowering of the humidity in the cave, which enhances evaporation. Thus, we exclude temperature as a major cause for the variability of $\delta^{18} \mathrm{O}$, because the range of $\delta^{18} \mathrm{O}$ would correspond to unrealistic changes of temperature of more than $4^{\circ} \mathrm{C}$.

The correlation of $\delta^{18} \mathrm{O}$ and $\delta^{13} \mathrm{C}$ (Fig. 4) gives evidence of periodic kinetic fractionation due to evaporation and fast degassing of $\mathrm{CO}_{2}$ [20], presumably as a consequence of lower humidity in the caves in summer when evapotranspiration above the cave is high [13]. The monitoring shows that the SI of dripping waters in summer is lower than in winter [13] and we infer that the summer dripping waters are mainly composed of winter rainfall, when less $\mathrm{CO}_{2}$ is produced in the soil above the cave. Periods of lower humidity in 


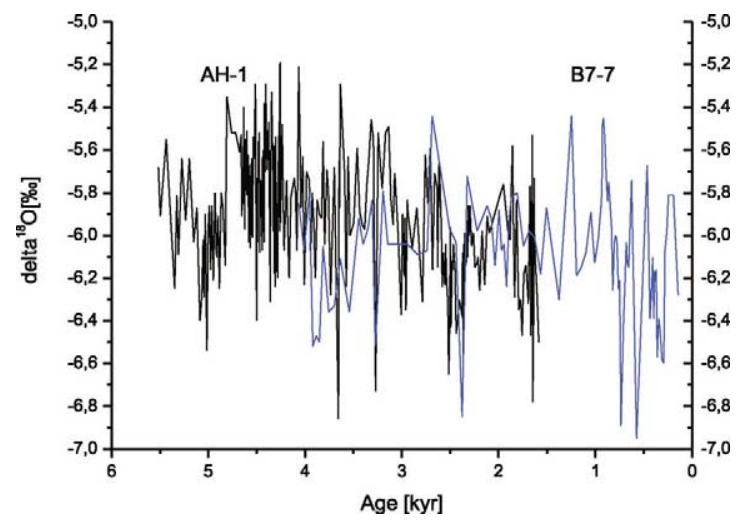

Fig. 6. Correlation of $\delta^{18} \mathrm{O}$ from stalagmites AH-1 and B7-7 (blue) (both scales tuned).

summer become even more probable, when less precipitation from the Northern Atlantic is brought into Northern Germany in winter. In summary, we ascribe the observed kinetic fractionation to less supply of water during drier and colder winters when the water reservoir above the cave remained at a lower stand and the cave dried out more frequently in summer.

The fact that AH-1 shows a behavior of $\delta^{18} \mathrm{O}$ with time in parts similar to that recorded in the B7-7 stalagmite, as shown in Fig. 6, suggests that periods of enhanced evaporation occurred on a regional scale, and are not a local phenomenon.

The spectral variance of the $\delta^{18} \mathrm{O}$ and the gray value records (Fig. 5) shows a major peak at 1450 $\mathrm{yr}$. This periodicity of $1450 \mathrm{yr}$ is dominant in the

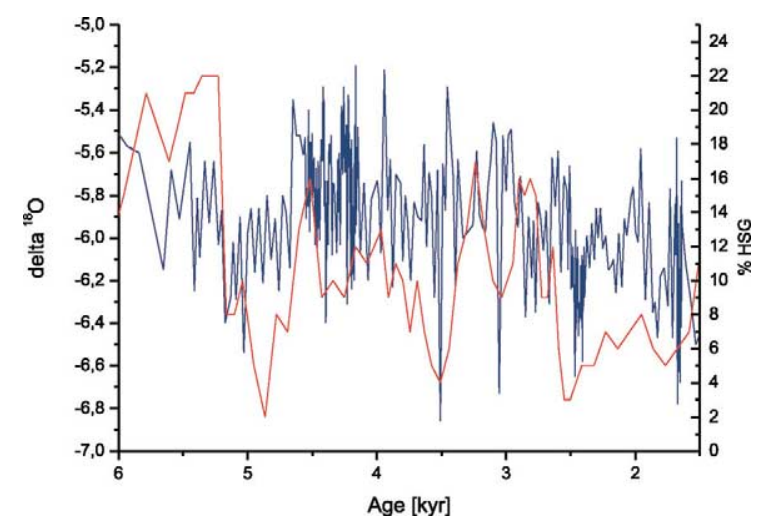

Fig. 7. Correlation of $\delta^{18} \mathrm{O}$ from stalagmite AH-1 (blue) and the hematite-stacked-grain record (red) of Bond (both scales untuned, [2]).
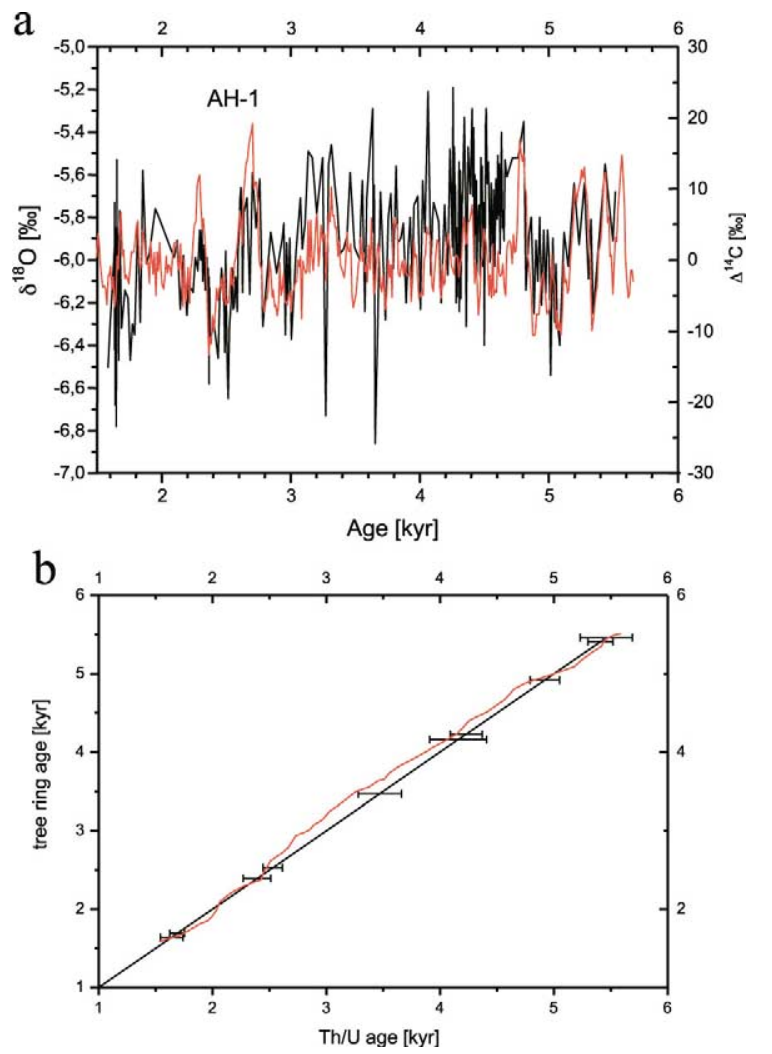

Fig. 8. (a) Comparison of the age profile of $\delta^{18} \mathrm{O}$ in $\mathrm{AH}-1$ (black curve) with the $\Delta^{14} \mathrm{C}$ from tree rings (red curve). The profile of $\delta^{18} \mathrm{O}$ was tuned to the radiocarbon profile within the limits allowed by the uncertainty of the ages as shown in b. The $\Delta^{14} \mathrm{C}$ time series was interpolated to the time points of the AH- $1 \delta^{18} \mathrm{O}$ time series, which is more coarsely resolved. The correlation coefficient is $0.42(\mathrm{CI}=[0.33 ; 0.51]$, $n=384$ ) obtained by 2000 simulations [19]. The confidence interval indicates that the correlation is significant at a high degree.

stalagmite record and suggests that it had a climatic impact in Northern Europe. The 1450 a cycle most probably is identical to the $1470 \mathrm{yr}$ Holocene cycle detected from ice rafted debris [hematite stained grains (HSG)] in North Atlantic sediment cores which is attributed to variations in solar irradiance [1,2]. Comparing the timing of the HSG with our $\delta^{18} \mathrm{O}$ record there is at least for the interval between 1.5 and $5 \mathrm{ka} \mathrm{BP}$ a strong coincidence (Fig. 7).

The coherence between $\delta^{18} \mathrm{O}$ of $\mathrm{AH}-1$ and the tree ring $\Delta^{14} \mathrm{C}$ is shown in Fig. 8a. The time scale for the $\delta^{18} \mathrm{O}$ values was tuned to best fitting of 
$\delta^{18} \mathrm{O}$ to the signal of $\Delta^{14} \mathrm{C}$. The correlation of $\delta^{18} \mathrm{O}$ and $\Delta^{14} \mathrm{C}$ was calculated for the age interval between 1.58 and $5.51 \mathrm{ka}$ BP by only slightly shifting the calendar scale within the limits allowed by the uncertainty of the $\mathrm{Th} / \mathrm{U}$ ages as shown in Fig. 8 b. $\Delta^{14} \mathrm{C}$ changes reflect solar forcing as shown by the correlation of $\Delta^{14} \mathrm{C}$ from tree rings and solar induced ${ }^{10} \mathrm{Be}$ flux in ice cores with the marine parameter of HSG as indicator for IRD in North Atlantic sediment cores [2].

The peaks of $\delta^{18} \mathrm{O}$ in the stalagmites indicate sections where calcite formed during periods of lower humidity in the cave, probably because of drier winters. At present the amount of winter precipitation in Northern Europe is related to the intensity of the Northern Hemisphere annular mode (NAM). Periodically stronger indices of NAM enhance the intensity of westerlies, which yields milder and wetter winters in Northern Europe [26]. The good correlation between $\delta^{18} \mathrm{O}$ and $\Delta^{14} \mathrm{C}$ promptly suggests that the periods of enhanced evaporation have occurred synchronous to periods of maximum radiocarbon content in the atmosphere. If the increase of atmospheric $\Delta^{14} \mathrm{C}$ corresponds to a less intense solar activity resulting in higher cosmic irradiation, our results then suggest that periods of lower intensity of solar irradiation were probably accompanied by drier climate in Northern Europe. This would require a periodic shifting towards weaker NAM indices. These periods become apparent in the 1450 a cycle which is for the first time detected in a continental archive of the North Atlantic influenced climate zone of Central Europe. The other periodicities at 117 and 94 yr at lower confidence are close to periodicities of the tree ring $\Delta^{14} \mathrm{C}$ record of 126 and $89 \mathrm{yr}$ [27], but more data are needed for a better accuracy on these minor signals.

\section{Conclusions}

The finding of the 1450 periodicity in the stalagmite $\mathrm{AH}-1$ together with the coherency to $\Delta^{14} \mathrm{C}$, which was also observed in stalagmite B77 , strongly supports the conclusions of Bond [1,2] derived from the amount of ice rafted detritus in highly resolved sediments in the Northern Atlantic. Our results suggest that variability of the Sun did also have a major impact on the pattern of precipitation in Northern Europe during the Holocene.

\section{Acknowledgements}

We thank Rene Eichstädter (Heidelberger Academy of Sciences) for measuring the TIMS data. W. Böhmer (Director of the Attendorner Tropfsteinhöhle, Attendorn) generously allowed sampling of speleothems and water in the Atta cave. Elmar Hammerschmidt and our friends from the Speleogroup Letmathe e.V. put at our disposal the cave map and technical equipment. S.N. and D.K.R. thank the Deutsche Forschungsgemeinschaft for financial support (SPP change of the geo-biosphere during the last $15000 \mathrm{yr}$; Ri 216/15).[BARD]

\section{References}

[1] G. Bond, W. Showers, M. Cheseby, R. Lotti, P. Almasi, P. deMenocal, P. Priore, H. Cullen, I. Hajdas, G. Bonani, A pervasive millennial-scale cycle in North Atlantic Holocene and glacial climates, Science 278 (1997) 1257-1266.

[2] G. Bond, B. Kromer, J. Beer, R. Muscheler, M.N. Evans, W. Showers, S. Hoffmann, R. Lotti-Bond, I. Hajdas, G. Bonani, Persistant solar influence on north Atlantic climate during the Holocene, Science 294 (2001) 2130-2136.

[3] C. Spötl, A. Mangini, Stalagmite from the Austrian Alps reveals Dansgaard-Oeschger events during isotope stage 3: Implications for the absolute chronology of Greenland ice cores, Earth Planet. Sci. Lett. 203 (2002) 507-518.

[4] C. Spötl, A. Mangini, N. Frank, R. Eichstädter, S.J. Burns, Start of the last Interglacial at $135 \mathrm{kyr}$ B.P.: Evidence from a high-alpine speleothem, Geology 30 (2002) 815-818.

[5] G. Wurth, S. Niggemann, N. Frank, A. Mangini, D.K. Richter, Jungquartäre Stalagmiten aus Höhlen des Gottesackergebietes (Allgäuer Alpen) als Archiv für Paläoumweltbedingungen, Karst Höhle 2000/01 (2000) 183-189.

[6] U. Neff, S.J. Burns, A. Mangini, M. Mudelsee, D. Fleitmann, A. Matter, Strong coherence between solar variability and the monsoon in Oman between 9 and $6 \mathrm{kyr}$ ago, Nature 411 (2001) 290-293.

[7] D. Fleitmann, S.J. Burns, M. Mudelsee, U. Neff, J. Kramers, A. Mangini, A. Matter, Holocene forcing of the Indian Monsoon recorded in a stalagmite from Southern Oman, Science 300 (2003) 1737-1739. 
[8] S.J. Burns, D. Fleitmann, M. Mudelsee, U. Neff, A. Matter, A. Mangini, A 780-year annually resolved record of Indian Ocean monsoon precipitation from a speleothem from south Oman, J. Geophys. Res. Atmos. 107 (2002) D20: 4434.

[9] J. Fantidis, D. Ehhalt, Variations of the carbon and oxygene isotopic composition in stalagmites and stalactites: evidence of non-equilibrium isotopic fractionation, Earth Planet. Sci. Lett. 10 (1979) 136-144.

[10] S. Niggemann, A. Mangini, D.K. Richter, G. Wurth, A paleoclimate record of the last 17,600 years in stalagmites from the B7-cave, Sauerland, Germany, Quat. Sci. Rev. 22 (2003) 557-569.

[11] Y.Y. Shopov, D.C. Ford, H.P. Schwarcz, Luminescent microbanding in speleothems: High-resolution chronology and paleoclimate, Geology 22 (1994) 407-410.

[12] R. Ahrweiler, Die Höhlen der Attendorn-Elsper Doppelmulde, Karst Höhle 1991/92 (1995) 11-204.

[13] S. Niggemann, Klimabezogene Untersuchungen an spätund postglazialen Stalagmiten aus Massenkalkhöhlen des Sauerlandes, Boch. Geol. Geotech. Arb. 55 (2000) 5-129.

[14] D. Genty, Y. Quinif, Annually laminated sequences in the internal structure of some Belgian stalagmites - importance for paleoclimatology, J. Sediment. Res. A 66 (1996) 275-288.

[15] D. Genty, A. Baker, W. Barnes, Comparaison entre les lamines luminescentes et les lamines visibles annuelles de stalagmites, C.R. Acad. Sci. Paris 320 (1997) 193-200.

[16] G. Wurth, S. Niggemann, D.K. Richter, Der hierarchische Aufbau des Laminationsgefüges eines spät/postglazialen Kerzenstalagmiten aus der Zoolithenhöhle bei Burggailenreuth (Fränkische Schweiz), Boch. Geol. Geotech. Arb. 55 (2000) 131-151.
[17] K.H. Wedepohl, The composition of the continental crust, Geochim. Cosmochim. Acta 59 (1995) 1217-1232.

[18] D. Genty, A. Baker, W. Barnes, M. Massault, Growth rate, grey level and luminescence of stalagmite laminae, Karst Water Inst. Spec. Publ. 2 (1996) 36-39.

[19] M. Mudelsee, Estimating Pearsons' correlation coefficient with bootstrap confidence interval from serially dependent time series, Math. Geol. 35 (2003) 651-665.

[20] C.H. Hendy, The isotopic geochemistry of speleothems. I. The calculation of the effects of different modes of formation on the composition of speleothems and their applicability as paleoclimatic indicators, Geochim. Cosmochim. Acta 35 (1971) 801-824.

[21] M. Schulz, M. Mudelsee, REDFIT: Estimating red-noise spectra directly from unevenly spaced paleoclimatic time series, Comput. Geosci. 28 (2002) 421-426.

[22] M. Mudelsee, TAUEST: A computer program for estimating persistence in unevenly spaced weather/climate time series, Comput. Geosci. 28 (2002) 69-72.

[23] J.H. Horne, S.L. Baliunas, A prescription for period analysis of unevenly sampled time series, Astrophys. J. 302 (1986) 757-763.

[24] M. Schulz, SPECTRUM and ENVELOPE: Computerprogramme zur Spektralanalyse nicht äquidistanter paläoklimatischer Zeitreihen, Ber. Sonderforschungsber. 313, Univ. Kiel No. 65, 1996, 131 pp.

[25] S. Verheyden, Speleothems as paleoclimatic archives, $\mathrm{PhD}$ thesis, University of Brussels, Brussels, 2001, 130 pp.

[26] D.W.J. Thompson, J.M. Wallace, Regional climate impacts of the Northern Hemisphere annular mode, Science 293 (2001) 85-89.

[27] M. Stuiver, T.F. Braziunas, Sun, ocean, climate and atmospheric ${ }^{14} \mathrm{CO}_{2}$ : an evaluation of causal and spectral relationships, Holocene 3 (1993) 289-305. 